\title{
Jacek Reginia-Zacharski
}

\author{
Wpływ doświadczeń z Bośni i Hercegowiny \\ w latach 1992-1995 na model i jakość dowodzenia \\ w operacjach pokojowych $\mathrm{ONZ}$ drugiej generacji
}

Operacje pokojowe Organizacji Narodów Zjednoczonych sa specyficznym fenomenem we współczesnych relacjach międzynarodowych. Uwaga ta odnosi się szczególnie do tzw. operacji pokojowych drugiej generacji, które jakkolwiek dookreślone zostały w latach 90 . XX w., realizowane były już znacznie wcześniej.

Jednym z bardziej złożonych problemów badawczych w tym obszarze jest kwestia użycia siły. Właśnie w odniesieniu do operacji „drugiej generacji” zagadnienie to nabrało szczególnej ostrości. Same operacje pokojowe nie znalazły swojego umocowania w podstawowym dla Organizacji dokumencie - Karcie Narodów Zjednoczonych. Intencją twórców statutu ONZ była realizacja postulatu pokojowego rozwiązywania sporów międzynarodowych. Na tę szczytną ideę nałożyły się uwarunkowania zimnowojenne, w wyniku których korzystanie z elementów siłowych dla utrzymywania i przywracania pokoju (a zatem środki inne niż mediacja i negocjacje) okazywało się wyjątkowo trudne. Tym bardziej że regulacje Karty Narodów Zjednoczonych wynikające z rozdz. VI i VII, w zdecydowany sposób sytuują możliwości decyzyjne w obszarze podlegającym Radzie Bezpieczeństwa. Tu, z uwagi na tryb „przyjmowania uchwał we wszystkich innych sprawach [niż proceduralne - J.R.-Z.]", możliwości decyzyjne bywały poważnie ograniczane przez fakt posiadania przez członków stałych Rady prawa veta. Nawet w przypadku przyjęcia rezolucji mocującej operację pokojowa (w okresie „zimnej wojny” ONZ „firmowała” trzydzieści dziewięć operacji pokojowych), problemem pozostawała relacja pomiędzy celem misji a granicami jej mandatu, szczególnie w odniesieniu do komponentu wojskowego. Jakkolwiek nigdy nie kwestionowano prawa „błękitnych hełmów” do użycia siły w sytuacji obrony koniecznej, głównym „zadaniem” dowodzących siłami wojskowymi w misjach pokojowych ONZ było unikanie zaostrzania sytuacji w relacjach pomiędzy stronami konfliktu na poziomach taktycznym i strategicznym oraz zachowanie bezdyskusyjnej bezstronności w sporze/konflikcie. O ile okazywało się to osiagalne w misjach utrzymywania pokoju, w warunkach stabilnego zawieszenia broni lub stałych rozwiązań pokojowych, to w sytuacji nawracajacych walk i incydentów zbrojnych prowadziło do sytuacji nierzadko kompromitujacych powagę Organizacji. 
Doświadczenia „zimowojennych” operacji pokojowych (UNEF i ONUC)

Przyjmuje się za pierwsze operacje pokojowe uznawać obecność wojskowych obserwatorów, których zadaniem było monitorowanie kruchych porozumień o zaprzestaniu walk, zawieszeniu broni i rozwiązywaniu sporów granicznych: w Grecji (1947-1951), Indonezji (1947-1951), Palestynie (od 1947 r.) i Kaszmirze (od 1948 r.) ${ }^{1}$. Następna dekada przyniosła wojnę koreańska, w której Organizacja występowała jako dawca prawomocnego mandatu, jednak same działania zbrojne zorganizowane były w oparciu o „koalicję chętnych”2. Zupełnie inaczej wyglądała już aktywność ONZ w czasie kryzysu sueskiego. United Nations Emergency Force (UNEF), które zostały stworzone w efekcie inicjatyw Daga Hammarskjölda, liczyły aż 6 tys. żołnierzy (początkowo 3,5 tys.), których zadania zostały określone znacznie szerzej niż w klasycznych misjach monitorujacych ${ }^{3}$. Notabene, warto zauważyć, że w tym czasie po raz pierwszy pojawiły się „błękitne hełmy”, jako wyposażenie żołnierzy noszących mundury armii narodowych. Sama idea operacji pokojowych tamtego okresu zakorzeniona była ściśle w rozdz. VI Karty Narodów Zjednoczonych, jednak już poczatek lat 60. XX w. wykazał, że niezbędne było szersze uwzględnienie działań w oparciu o rozdz. VII, wobec zadań w środowisku „bez pokoju do utrzymania”. Pewną próbą wyjścia z tej sytuacji była koncepcja Sekretarza Generalnego ONZ, opisana jako działania z zakresu „rozdziału VI i pół”. Problem wywołany został przez D. Hammarskjölda w związku z tym, że UNEF operowały w oparciu o decyzję Zgromadzenia Ogólnego, na mocy art. 14 Karty NZ. Pominięto w tym przypadku procedury rozdz. VII, w oparciu o które Rada Bezpieczeństwa mogłaby autoryzować użycie siły. UNEF natomiast nigdy nie były postrzegane jako klasyczna operacja z zakresu rozdz. VI. W oparciu o taka złożoną i nietypową sytuację prawną misji powstał wzorzec łańcucha dowodzenia dla późniejszych operacji pokojowych ONZ. Dowódca misji w polu został kanadyjski gen. Eedson Louis Millard Burns, który odpowiadał bezpośrednio przed Sekretarzem Generalnym. Ten zaś składał sprawozdania przed Zgromadzeniem Ogólnym ${ }^{4}$. Za determinacją Hammarskjölda i Burnsa nie szły jednak możliwości wojskowe. Według szacunków zaangażowanie stron konfliktu wymagałoby wyposażenia UNEF w komponent wojskowy składajacy się z dywizji piechoty, brygady pancernej, wsparcia lotniczego oraz solidnego rozpoznania. Takie rozwiązanie ze względów politycznych było niemożliwe do realizacji. Misja pozostawała w wymiarze

${ }^{1}$ E.A. Schmidl, The Evolution of Peace Operations from the Nineteenth Century, [w:] Peace Operations between War and Peace, ed. E.A. Schmidl, London 2000, s. 10.

2 Por.: tamze, s. 10-11; T. Findlay, The Use of Force in UN Peace Operations, Oxford 2002 , s. $7-9$

${ }^{3}$ The Blue Helmets. A Review of United Nations Peace-keeping, New York 1996, s. 43.

${ }^{4}$ T. Findlay, $d z$. cyt., s. 21-22. W następnych latach łańcuch odpowiedzialności kończył się na Sekretarzu Generalnym, który w terenie z reguły był reprezentowany przez Specjalnego Przedstawiciela (Special Representative of Secretary General). 
Wpływ doświadczeń z Bośni i Hercegowiny w latach 1992-1995...

wojskowym zjawiskiem bardziej symbolicznym niż w rzeczywistości odstraszajacym $^{5}$. Mimo tego, działalność UNEF oceniona została pozytywnie ${ }^{6}$.

Prawdziwym wyzwaniem dla ONZ stał się konflikt w Kongu. Wojna, która wybuchła w tym kraju zaraz po ogłoszeniu niepodległości, wymuszała zaangażowanie Organizacji. Tym bardziej, że atmosfera podczas sprawowania urzędu Sekretarza Generalnego przez D. Hammarskjölda zdecydowanie sprzyjała aktywności w tego typu konfliktach. Głównym problemem w kongijskiej wojnie domowej była secesja prowincji Katanga. Pociagało to za sobą określone konsekwencje. Od samego początku wydarzenia w Kongu nie dawały się wpisać w konflikt pomiędzy dwoma podmiotami politycznymi, lecz dotyczyły zderzenia zasad integralności terytorialnej i prawa do samostanowienia. Ostatecznie stanowisko ONZ określała rezolucja Rady Bezpieczeństwa nr 145 z lipca 1960 r. Odnosząc się do innej zasady - nieingerencji - żądano, by wszystkie podmioty państwowe powstrzymały się od angażowania się w „,...] jakakkolwiek akcję, która mogłaby utrudniać odbudowę rządów prawa i porządku” w Kongu? ${ }^{7}$ W odniesieniu do „prawności” ewentualnej secesji Katangi użyto interesującej konstrukcji logicznej, wychodząc z założenia, że Organizacja przyjęła w swoje szeregi Kongo jako całość. Stało się to podstawa do umocowania Sekretarza Generalnego, jako dysponenta szerokich środków dla osiagnięcia zakładanych celów. Część z celów została określona w cytowanej rezolucji, część we wcześniejszej nr $143^{8}$. W rezolucji nr 146 z 9 sierpnia 1960 r., w paragrafie 3 znalazły się znamienne słowa, iż Rada Bezpieczeństwa „[...] uznaje, że wejście sił Narodów Zjednoczonych do prowincji Katanga jest niezbędne dla pełnej realizacji obecnej rezolucji”" Wobec braku zgody reżimu Moise Czombego na takie rozwiązanie sytuacja stawała się krytyczna. Dopiero osobiste zaangażowanie Sekretarza Generalnego

${ }^{5}$ N.D. White, The United Nations and the Maintenance of International Peace and Security, Manchester 1990, s. 218.

${ }^{6}$ Szerzej na temat uwarunkowań operacji i szczegółowych ocen patrz: From Report to the General Assembly on Liquidation of UNEF, New York, July 12, 1967, [w:] Public Papers of the Secretaries-General of the United Nations, vol. 7 (1965-1967), New York 1976, s. $480-489$.

7 United Nations Document (dalej: UN) S/4405, 145 (1960), Resolution of 22 July 1960. Szczególna uwagę zwracano na wycofanie sił belgijskich z nowej republiki.

${ }^{8}$ UN S/4387, 143 (1960), Resolution of 14 July 1960. „Rada Bezpieczeństwa [...] upoważnia Sekretarza Generalnego do podjęcia niezbędnych środków, w porozumieniu z rządem Republiki Konga, by zapewnić temu rządowi niezbędne wsparcie wojskowe do czasu, gdy wysiłki kongijskiego rządu przy technicznym wsparciu Narodów Zjednoczonych, doprowadzą narodowe siły bezpieczeństwa [...] do pełnej zdolności realizacji ich zadań”.

9 UN S/4426, 146 (1960), Resolution of 9 August 1960. Co prawda, w następnym paragrafie potwierdzano, iż siły Narodów Zjednoczonych nie będą opowiadać się po żadnej ze stron konfliktu, jednak wymowa całego dokumentu była jednoznaczna. Można się zastanawiać, na ile bliskie prawdy sa nieco „literackie” tytuły o „pierwszej wojnie ONZ”. Ton rezolucji nr 146 i wcześniejszych pozostawiał wiele watpliwości co do deklarowanej bezstronności Organizacji. 
i bezpośrednie rozmowy z Czombem dały efekt w postaci pokojowego rozmieszczenia Operacji Organizacji Narodów Zjednoczonych w Kongu (ONUC) ${ }^{10}$ na obszarze Katangi. Mimo formalnego spełnienia warunku zgody stron konfliktu na obecność wojsk w „błękitnych hełmach” w polu (i w rzeczywistości) ich sytuacja była trudna. W szczególności w Katandze, gdzie pozostający na żołdzie M. Czombego najemnicy postrzegali (i nierzadko traktowali) oddziały ONUC jako siłę wroga. Szczególnie ciężka okazała się druga połowa 1961 r., kiedy oddziały międzynarodowe w wyniku rozpoczętej operacji „Morthor” znalazły się w centrum regularnych działań wojennych ${ }^{11}$ - głównie w Elisabethville - choć starcia miały miejsce również w innych częściach Katangi. Operacja została przeprowadzona w oparciu o rezolucję Rady Bezpieczeństwa nr 161 z lutego 1961 r., w której Rada wzywała do usunięcia z Katangi wojsk obcych i przede wszystkim najemników ${ }^{12}$. W tym czasie - właśnie w wyniku zaostrzenia się sytuacji w Katandze -znacznie skomplikowała się sytuacja D. Hammarskjölda. Z jednej strony mandat misji (i tak już szeroki) mimo wszystko ograniczał użycie siły w celach „ofensywnych”, z drugiej - na forum Organizacji Sekretarz coraz częściej stawał się przedmiotem ataków - co ciekawe - z obu stron „żelaznej kurtyny”. Blok krajów socjalistycznych krytykował realizację misji za spowalnianie działań, co miało służyć interesom „kolonizatorów”. Z drugiej strony, na Zachodzie niejednokrotnie dochodziły do głosu opinie, w myśl których brak zdecydowanych działań ze strony ONZ wydłużał konflikt, narażając na szwank reputację Organizacji i życie uczestników misji. Ten wzrost napięcia skłonił D. Hammarskjölda do podjęcia misji rozpoczęcia kolejnej tury rozmów z M. Czombem. W dniu 17 wrzenia $1961 \mathrm{r}$. Sekretarz Generalny zginą w katastrofie lotniczej, gdy udawał się do Rodezji. Jakkolwiek Czombe, pod wrażeniem tej tragedii, dwa dni później zdecydował się na porozumienie wojskowe, które w ciagu tygodnia weszło w życie i zostało

${ }^{10}$ ONUC (Organisation des Nations Unies au Congo, United Nations Operation in the Congo) ustanowiona została na mocy rezolucji nr 143 (1960) - UN S/4387, Resolution of 14 July 1960: ,[...] to authorize the Secretary-General to take the necessary steps, in consultation with the Government of the Republic of the Congo, to provide the Government with such military assistance as might be necessary until, through that Government's efforts with United Nations technical assistance, the national security forces might be able, in the opinion of the Government, to meet fully their tasks" - por. J. Boulden, Peace Enforcement. The United Nations Experience in Congo, Somalia, and Bosnia, Westport 2001, s. 26-27. Zob. też: J. Sołtysiak, Działania wojsk ONUC wobec secesji Katangi (sierpień 1960-styczeń 1963), „Acta Universitatis Lodziensis” 2005, Folia Historica 79, s. 112

11 J. Boulden, Peace Enforcement..., s. 35-36.

12 UN S/4741, 161 (1961), Resolution of 21 February 1961. Por. H. Nasu, International Law on Peacekeeping. A Study of Article 40 of the UN Charter, Leiden 2009, s. 186-187. Autor zwraca uwage na to, że efekty operacji „Morthor” stały w całkowitej sprzeczności z założeniami rezolucji $\mathrm{nr} 161$. Również użycie siły znacznie wykraczało poza mandat ONUC i ramy zakreślone w rezolucji $\mathrm{nr} 161$. Warto odnotować, że przeprowadzona miesiąc wcześniej w Elisabethville operacja „Rumpunch”, zaplanowana i wykonana została w sposób, dzięki któremu udało się uniknać krwawych starć, J. Sołtysiak, dz. cyt., s. 114-115. 
Wpływ doświadczeń z Bośni i Hercegowiny w latach 1992-1995...

zaakceptowane przez ONZ, to już w październiku i listopadzie siły ONUC ponownie znalazły się $\mathrm{w}$ ogniu walk, tym razem $\mathrm{z}$ armia kongijska. Zaostrzenie się sytuacji wojsk ONUC zaowocowało przyjęciem 24 listopada 1961 r. rezolucji Rady Bezpieczeństwa nr 169, w której poza szeregiem wytycznych upoważniono Sekretarza Generalnego do podjęcia działań przy użyciu wszelkich środków (z siłą włącznie) w celu opanowania sytuacji i ukarania winnych ${ }^{13}$.

Kwestia użycia siły w Kongu przeszła w ciągu półtora roku długą drogę. Pierwsze zalecenia D. Hammarskjölda z czerwca 1961 r. oparte były na doświadczeniach UNEF. Sekretarz Generalny przewidywał: „Oddziały zaangażowane $\mathrm{w}$ operację nie moga podejmować inicjatyw w użyciu siły zbrojnej, ale sa uprawnione do stosowania siły dla odparcia ataku z użyciem broni, w tym działań na rzecz usunięcia sił wrogich z miejsc, określonych przez dowódcę, działającego w zakresie rezolucji z upoważnienia Rady Bezpieczeństwa"14. Widoczne tu jest pozostawienie furtki dla podejmowania działań siłowych wykraczających poza samoobronę i idących w kierunku realizowania celów misji. Rozwiązanie to zostało jednak poważnie ograniczone poprzez obowiązek ścisłej autoryzacji działań przez Radę Bezpieczeństwa z pominięciem elementów operacyjnych $\mathrm{i}$ inicjatywy dowódcy w polu. Interesująca wykładnię w obszarze mandatu ONUC dano również w opinii Międzynarodowego Trybunału Sprawiedliwości z 1962 r. Stwierdzono tam, że zakres działań siłowych misji był ograniczony z uwagi na brak rezolucji Rady Bezpieczeństwa, wynikającej z rozdz. VII Karty NZ (art. 39), w której wskazywano by stronę (państwo) winne agresji lub naruszenia pokoju ${ }^{15}$. Mimo to operacja „Morthor” z punktu widzenia wojskowego posiadała wiele aspektów ofensywnych.

\section{Początki „rules of engagement” i Agenda dla Pokoju}

Działania w Kongu ostatecznie przekonały, iż „zasady obecności” czy może „zasady użycia siły”16 (rules of engagement) operacji pokojowych ONZ sa wypadkową trzech czynników (por. schemat 1):

- prawa, które należy rozumieć jako zakres wyznaczany przez mandat misji w oparciu o rezolucję Rady Bezpieczeństwa lub Zgromadzenia Ogólnego oraz działania Sekretarza Generalnego;

${ }^{13}$ UN S/5002, 169 (1961), Resolution of 24 November 1961. Zob. też D.W. Bowett, G.P. Barton, R. Higgins, United Nations Forces. A Legal Study, New York 2008, s. 181-182.

${ }^{14} \mathrm{UN}$ S/4389, First Report of the Secretary-General on the Implementation of Security Council Resolution S/4387 of 14 July 1960, 18 July 1960.

15 Por. T. Findlay, $d z$. cyt., s. 54-55.

${ }^{16} \mathrm{~W}$ terminologii stosowanej przez polskie Dowództwo Operacyjne Sił Zbrojnych przyjęto tłumaczenie: „zasady użycia siły” - zob.: http://www.do.wp.mil.pl/ktualnosc.php? idaktualnosc= 111 (dostęp 1 II 2011). 
- polityki, czyli woli członków Organizacji - ze szczególnym uwzględnieniem stanowiska członków stałych Rady Bezpieczeństwa, ale także innych państw i innych aktorów zainteresowanych konfliktem;

- misji, czyli względów operacyjnych, pozostających w gestii Specjalnego Reprezentanta Sekretarza Generalnego i głównodowodzącego oddziałami zaangażowanymi w misji.

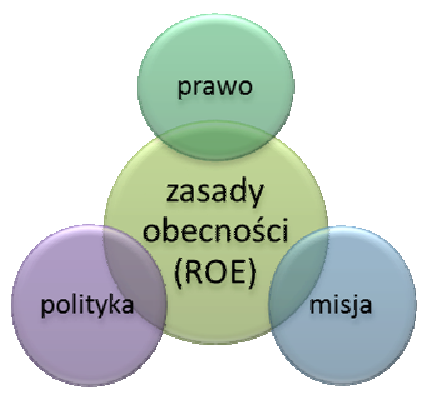

Schemat 1

Już pierwsze operacje pokazały, że trzecia grupa czynników warunkujacych pozostawała w cieniu dwóch pozostałych. Zakres zadań był zmieniany w trakcie wykonywania misji - co było zrozumiałe - z uwagi na labilną sytuację w kraju ogarniętym wojną. Problemy stwarzał natomiast fakt, ze decyzje podejmowano w Nowym Jorku, co sprawiało, że często były one nieadekwatne do rozwoju sytuacji bądź w najlepszym razie - mocno opóźnione. UNEF i ONUC ostatecznie określały łańcuch dowodzenia (według schematu 2):

\section{Schemat 2}

Właściwie w oparciu o zapowiedzi, wynikające z art. 47 Karty NZ łańcuch dowodzenia zaplanowany został nieco inaczej. Przewidywano utworzenie Wojskowego Komitetu Sztabowego, który miał „służyć Radzie Bezpieczeństwa radą i pomoca we wszystkich sprawach, dotyczących wojskowych potrzeb Rady w zakresie utrzymania międzynarodowego pokoju i bezpieczeństwa, użycia oddanych do jej rozporządzenia sił zbrojnych i dowodzenia nimi, regulowania 
Wpływ doświadczeń z Bośni i Hercegowiny w latach 1992-1995...

zbrojeń i możliwego rozbrojenia"17. Zadania Komitetu zostały opisane w formule: „Wojskowy Komitet Sztabowy, podlegając Radzie Bezpieczeństwa, odpowiada za strategiczne kierownictwo wszelkimi siłami zbrojnymi, oddanymi do dyspozycji Rady Bezpieczeństwa"18. Taka instytucja, mimo podejmowanych w latach 40 . prób $^{19}$, w okresie „zimnej wojny” nie osiagnęła możliwości sprawnego funkcjonowania $^{20}$. Status Wojskowego Komitetu Sztabowego (podobnie zreszta jak art. 45 Karty NZ) określany był jako „uśpienie”, bądź „nieaktywność”. Komitet pozostawał „pomnikiem wyblakłych nadziei założycieli Narodów Zjednoczonych”21.

Wracając do „zasad zaangażowania” powiedzieć trzeba, że stanowią one zespół zasad, w oparciu o które oddziały, delegowane do wykonywania operacji pokojowej, moga używać siły. Wykonywanie zadań limitowane jest przede wszystkim zakresem mandatu opracowanego bądź zatwierdzonego przez Radę Bezpieczeństwa. Zaryzykować można stwierdzenie, że konstrukcja mandatu odnosi się przede wszystkim do sfery strategicznej, natomiast „rules of engagement" mają stanowić przełożenie założeń strategicznych do sfery taktycznej22. Wpisuje się to zresztą w opisany powyżej łańcuch dowodzenia. Jak zaznaczono, „rules of engagement" stanowią amalgamat regulacji operacyjnych i politycznych, uzupełniony regulacjami na poziomie taktycznym, dotyczacymi zasad użycia sił zbrojnych w ramach mandatu operacji. „Zasady zaangażowania” konstruowane były do 2002 r., autonomicznie dla każdej operacji pokojowej, ale już od czasu ONUC widoczny był pewien ogólny wzór konstrukcyjny. „Rules of engagement” zawierały dwa cele: samoobronę oraz - w nieco mniejszym stopniu - wykonanie misji23. Jak przekonywała praktyka operacji pokojowych okresu „zimnej wojny”, akcent przy konstruowaniu „zasad zaangażowania” zdecydowanie przesunięty był na samoobronę żołnierzy bioracych udział w misji, niekiedy kosztem celu operacji.

${ }^{17}$ Karta Narodów Zjednoczonych, art. 47, § 1, [w:] Organizacje międzynarodowe. Wybór tekstów źródtowych, red. H. Horbaczewski, J. Reginia-Zacharski, Włocławek 2008, s. 42. Wojskowy Komitet Sztabowy miał sie składać „....] z szefów sztabów stałych członków Rady Bezpieczeństwa albo ich przedstawicieli. Członkowie Narodów Zjednoczonych, którzy nie mają stałych przedstawicieli w Komitecie, zapraszani sa do udziału w jego pracach, o ile udział danego członka jest potrzebny do skutecznego wykonania przez Komitet jego zadań” (§ 2).

${ }_{18}^{18}$ Tamże, $\S 3$.

19 P. Chmielewski, Dyplomacja sowiecka w Radzie Bezpieczeństwa ONZ wobec zadań utrzymania pokoju i bezpieczeństwa międzynarodowego u progu „zimnej wojny”, Łódź 2005, t. II, s. 401 in.

${ }^{20}$ Szerzej: J. Boulden, Prometheus Unborn. The History of the Military Staff Committee, „Aurora Papers”, no. 19, Ottawa 1993.

${ }^{21}$ E. Grove, U.N. Armed Forces and the Military Staff Committee: A Look Back, „International Security” 1993, vol. XVII, no. 4, s. 172-182. Po zakończeniu „zimnej wojny” można zaobserwować próby ożywienia tej instytucji.

${ }^{22}$ R.J. Grunawalt, The JCS Standing Rules of Engagement: A Judge Advocate's Primer, „Air Force Law Review” 1997, vol. 42, s. 245-246. Patrz też: Rules of Engagement (ROE) Handbook for Judge Advocates (1 May 2000), Charlottesville 2000, s. 1-2.

${ }^{23}$ R.J. Grunawalt, $d z$. cyt., s. 247. 
Doskonale pokazuja to cztery grupy dopuszczalnych zachowań opisanych w mandacie ONUC. Sił zbrojnych można było użyć w przypadku: 1) podejmowania przez oddziały wrogie starań o usunięcie sił ONZ z pozycji już zajmowanych; 2) podejmowania prób rozbrojenia „błękitnych hełmów”; 3) podejmowania przez siły wrogie działań mogacych grozić sprzętowi i kwaterom ONZ oraz stwarzania zagrożenia dla personelu cywilnego misji; 4) podejmowania przez siły wrogie akcji utrudniających wykonywanie rozkazów, wydanych żołnierzom przez przełożonych $^{24}$. Jak widać, cel misji - czyli realizacja zadania i pozostawienie swobody dowódcom w polu - nie zostały ujęte wśród priorytetów, dopuszczających użycie siły.

Taka sytuacja trwała do zakończenia „zimnej wojny”. Wydawało się, że rok 1992 przyniesie zmianę w systemie operacji pokojowych ONZ, tym bardziej, że urząd Sekretarza Generalnego objął Boutros Boutros-Ghali, od początku zapowiadajacy intensywne działania w tym sektorze.

W dokumencie Agenda for Peace, opublikowanym ostatecznie 17 czerwca 1992 r., Sekretarz Generalny Organizacji wychodził od stwierdzenia o istniejacym ówcześnie, znacznie zmienionym kontekście stosunków międzynarodowych ${ }^{25}$. Podkreślony został efekt otwartości, jaki wydawał się realizować w związku z końcem „zimnej wojny”, co zostało przez B. Boutrosa-Ghalego zinterpretowane jako zjawisko pozytywne. Sekretarz dostrzegał tendencję do rozszerzania się sfery demokracji i gospodarki wolnorynkowej. Obok tego wskazywano na znaczny wzrost liczby członków ONZ, wynikajacy z trwającej od początku istnienia Organizacji fali wolnościowo-niepodległościowej, której kolejny etap rozpoczą się pod koniec lat 80 . XX w. ${ }^{26}$ Jednocześnie Sekretarz Generalny zwracał uwage na narastające problemy związane $\mathrm{z}$ bezpieczeństwem światowym ${ }^{27}$. Konsekwencja tej refleksji było wskazanie na ogrom ofiar i spustoszeń, jakie w okresie formalnej nielegalności wojny, zjawisko to spowodowało. Pociagało to za sobą konieczność redefinicji i dookreślenia celów ONZ w tej dziedzinie. Wśród nich, jako główne wymieniano:

\footnotetext{
${ }^{24}$ H. Nasu, $d z . c y t .$, s. 190.

${ }_{25}$ UN A/47/277 - S/24111, An Agenda for Peace. Preventive Diplomacy, Peacemaking and Peace-keeping. Report of the Secretary-General Pursuant to the Statement Adopted by the Summit Meeting of the Security Council on 31 January 1992, §§ 9-19.

${ }^{26}$ M.N. Barnett, The Limits of Peacekeeping, Spheres of Interests and the Future of the United Nations, [w:] Collective Conflict Management and Changing World Politics, ed. J. Lepgold, T.G. Weiss, New York 1999, s. 83-90.

27 UN A/47/277 - S/24111, § 12 . „W tym nowym wymiarze zagrożenia nie wolno dopuścić do przesłonięcia faktu, iź głównym źródłem sprzeczności sa: przewlekłe i szkodliwe zjawiska niekontrolowanego wzrostu populacji, ogromnego zadłużenia, barier handlowych, narkotyków i rosnących dysproporcji między bogatymi i biednymi. Ubóstwo, choroby, głód, ucisk i rozpacz, dały efekt $17 \mathrm{mln}$ uchodźców, $20 \mathrm{mln}$ osób przesiedlonych oraz masowe migracje wewnętrzne i zewnętrzne" [tłum. autora] - tamże, § 13.
} 
- stworzenie systemu wczesnej identyfikacji sytuacji konfliktogennych i usuwania przyczyny na drodze dyplomatycznej przed wejściem kryzysu w fazę przemocy;

- w sytuacji wybuchu konfliktu prowadzenie działań z zakresu „peacemaking" w celu usunięcia lub spacyfikowania kryzysu;

- poprzez działania z zakresu „peacekeeping” utrzymywanie „kruchego” pokoju (rozumianego jako wstrzymanie działań wojennych) i umożliwianie realizacji zadań z zakresu „peacemaking”;

- osiagnięcie stałej zdolności do prowadzenia akcji budowania pokoju (,peacebuilding”);

- w szerokim zakresie dążenie do usuwania głównych przyczyn zagrożenia pokoju (niedostatków gospodarczych, niesprawiedliwości społecznej i politycznego ucisku) ${ }^{28}$

Niezbędnym i twórczym rozwinięciem tak zarysowanego programu było wprowadzenie do systemu funkcjonowania ONZ elementu definicyjnego w zakresie operacji pokojowych ${ }^{29}$. O ile zgodzić się trzeba ze stwierdzeniami, iż działania tego rodzaju obecne były w praktyce ONZ niemal od początku jej funkcjonowania, to nie ulega wątpliwości, że brak definicji w tej sferze aktywności powodował w dekadach poprzedzających Agende dla Pokoju spore trudności i zamieszanie. Niewątpliwie jednak wprowadzenie definicji kolejnych etapów działań pokojowych - z jednej strony wychodząc naprzeciw starym problemom - generowało nowe. Dostrzegając zjawisko chroniczności współczesnych konfliktów zbrojnych, Sekretarz Generalny postulował konieczność doposażenia tradycyjnych misji pokojowych, konstruowanych w oparciu o literę rozdz. VI Karty NZ, komponentem niedoprecyzowanych, ,peaceenforcement units" ${ }^{30}$. Podstawa prawna ich funkcjonowania miała być szczególna interpretacja art. 40 Karty ${ }^{31}$, a ich działanie

${ }^{28}$ Tamże, $\S 15$.

${ }_{29}^{2}$ Obowiazujace definicje: „Dyplomacja prewencyjna jest działaniem w celu zapobiegania powstawaniu sporów pomiędzy stronami, w celu zapobieżenia eskalacji istniejących sporów i konfliktów w celu ograniczenia rozprzestrzeniania się tych ostatnich, kiedy one wystapia. [...] Peacemaking sa to działania w celu doprowadzenia wrogich stron do porozumienia, głównie za pośrednictwem takich środków pokojowych, jakie przewidziano w rozdz. VI Karty Narodów Zjednoczonych. [...] Peacekeeping stanowi rozmieszczenie sił pokojowych Narodów Zjednoczonych w terenie, jednak za zgoda wszystkich zainteresowanych stron, zwykle z udziałem sił wojskowych Organizacji Narodów Zjednoczonych i/lub personelu policyjnego oraz przedstawicieli cywilnych. Peacekeeping jest technika, która rozszerza możliwości zarówno zapobiegania konfliktom, jak i tworzenia pokoju" - tamże, $\S 20$. Patrz też M.W. Doyle, N. Sambanis, Making War and Building Peace. United Nations Peace Operations, Princeton 2006, s. 10.

${ }^{30} \mathrm{UN} \mathrm{A} / 47 / 277-\mathrm{S} / 24111, \S \S 40-41$

31 Karta Narodów Zjednoczonych, Statut Międzynarodowego Trybunału Sprawiedliwości i Porozumienie ustanawiające Komisję Przygotowawcza Narodów Zjednoczonych (Dz.U. z dnia 6 marca 1947 r. - Dz.U. 47.23.90): „Art. 40. Aby zapobiec zaostrzeniu się sytuacji, Rada Bezpieczeństwa może, przed udzieleniem zaleceń lub wydaniem decyzji 
winno być traktowane rozdzielnie w stosunku do jakichkolwiek sił działających na mocy decyzji Rady Bezpieczeństwa w oparciu o art. 43. Sekretarz wskazywał na praktyczną stronę zagadnienia utrwalania pokoju, podkreślając, że okres pomiędzy sukcesem negocjacyjnym w ramach „peacemaking” a rozpoczęciem działań utrzymywania pokoju stanowi niejednokrotnie moment krytyczny właściwy dla działania „peaceenforcement units”32.

Nowe zadania miały być realizowane w ramach tzw. misji pokojowych drugiej generacji, do których zaliczano zadania monitorowania wykonywania zawieszenia broni, rozbrojenia i demilitaryzacji obszaru po konflikcie, jak też odbudowę struktury sił zbrojnych i policyjnych oraz nadzorowanie rozwoju sytuacji w kierunku demokratyzacji ${ }^{33}$.

W ten sposób B. Boutros-Ghali otwierał szeroko dyskutowane i krytykowane ${ }^{34}$ pole dla decyzji z obszaru operacji „rozdziału VI i pół” Karty $N Z^{35}$. Reakcja na ogłoszenie tez zawartych w Agendzie dla Pokoju stanowiła zapewne zaskoczenie dla pomysłodawców. Dyplomacja Republiki Francuskiej odniosła się do koncepcji z dużym entuzjazmem - czego efektem było niemal natychmiastowe zadeklarowanie 1 tys. żołnierzy dla realizacji złożonych zadań pokojowych ${ }^{36}$. Z pewną rezerwa, która szybko przerodziła się w pełne poparcie „Programu”, podeszli do inicjatywy Amerykanie ${ }^{37}$ i Brytyjczycy ${ }^{38}$. Zaskakujące na pierwszy rzut oka było natomiast stanowisko wielu krajów rozwijających się, do których „oferta

o zastosowaniu środków przewidzianych w art. 39, wezwać strony zainteresowane, aby zastosowały się do zarządzeń tymczasowych [podkr. - J.R.-Z.], jakie Rada uzna za konieczne lub pożądane. Takie zarządzenia tymczasowe nie przesądzają praw, roszczeń lub stanowiska stron. Rada Bezpieczeństwa wyciagnie odpowiednie wnioski z niezastosowania się do takich zarządzeń".

32 UN A/47/277 - S/24111, § 45: „Ponieważ dyplomacja obecna jest w całej gamie działań omówionych w niniejszym sprawozdaniu, nie może więc być wytyczona wyraźna granica między przywracaniem i utrzymywaniem pokoju. Peacemaking często jest wstępem do peacekeeping - podobnie, rozmieszczenie obecności Narodów Zjednoczonych w terenie może rozszerzyć możliwości zapobiegania konfliktom, ułatwia pracę na rzecz przywracania pokoju i w wielu przypadkach stanowi warunek wstępny dla budowania pokoju”.

${ }^{33}$ Y. Choedon, China's Stand on UN Peacekeeping Operations: Changing Priorities of Foreign Policy, „China Report” 2005, vol. 41, no. 1, s. 39-40.

${ }^{34}$ M.W. Doyle, N. Sambanis, dz. cyt., s. 69-70.

35 Określenie zostało użyte przez D. Hammarskjölda po doświadczeniach ONZ w czasie kryzysu sueskiego w 1956 r. W latach 90. pojawiło się podczas debaty British House of Commons w 1993 r. - cyt. za: T. Findlay, dz. cyt., s. 161.

36 Tamże, s. 162 . Autor podkreślał niechęć strony francuskiej do posługiwania się proponowaną w Agendzie retoryką. Zdecydowanie unikano używania określeń z dziedziny „planowania operacyjnego", opowiadając się za tradycyjnym podejściem „celowym” (utrzymywanie, budowanie pokoju).

37 Szerzej: V.K. Holt, Briefing Book on Peacekeeping. The U.S. Role in United Nations Peace Operations, Washington 1994, s. 14-15.

38 Zob. T.G. Weiss, S. Daws, The Oxford Handbook on the United Nations, Oxford 2007, s. 200-201. 
Wpływ doświadczeń z Bośni i Hercegowiny w latach 1992-1995...

bezpieczeństwa" głównie była skierowana. Przedstawiciele tych państw, odnosząc się do wysokich standardów technologicznych, jakie musiałyby spełniać wojska biorace udział $\mathrm{w}$ misjach pokojowych, podejrzewali przekształcenie się tych operacji w bliżej nieokreśloną formę „neoimperializmu bezpieczeństwa”, którego eksporterami miały być kraje rozwinięte, dysponujące zaawansowaną technologia. Podobne zastrzeżenia płynęły zresztą od krajów niezaliczanych do „trzeciego świata”. Brazylia, Indie, Malezja, Pakistan zgłosiły do nowej koncepcji szereg uwag, wśród których dominowało przekonanie o możliwościach łamania fundamentalnej dla Organizacji Narodów Zjednoczonych zasady suwerenności państw ${ }^{39}$. Wątpliwości dobrze scharakteryzował Adam Roberts, pisząc: „[...] dobrze sprawdzone w ONZ mechanizmy utrzymywania pokoju zostały zachwiane i najprawdopodobniej osłabione, bez należytej dyskusji na temat możliwych implikacji. Po drugie, wiele osób i krajów (głównie małych i/lub rozwijających się) poczuło się zagrożonych przez nowy, interwencyjny peacekeeping" 40 . David Jablonsky wskazywał na inną słabość proponowanych rozwiązań. Zasady „zgody i bezstronności” wydawały się zbyt słabą podstawą dla stworzenia czytelnej i efektywnej doktryny operacji pokojowych. Pojawienie się propozycji rozpowszechnienia „misji drugiej generacji" (robust, muscular) w prosty sposób mogło prowadzić do wniosku, iż w szczególnych przypadkach użycie obcych sił wojskowych na danym terenie mogłoby być realizowane bez potrzeby pełnego mandatu międzynarodowego. Z militarnego (czyli efektywnego) punktu widzenia takie stanowisko było w pełni uzasadnione. Jakość oraz rozmiar użytych sił uzależnione byłyby od rodzaju zadania, a nie od politycznego kompromisu osiąnniętego w odległej od centrum konfliktu siedzibie Organizacji ${ }^{41}$. Polityczne wypracowanie takich rozwiązań było jednak bardzo skomplikowane. Brak wyraźnego rozdzielenia operacji w oparciu o art. VI i VII Karty NZ, pociagał za soba trudne do przewidzenia komplikacje już podczas planowania i realizacji misji. „Nie jest [bowiem] zadaniem łatwym prowadzenie wojny i konstruowanie pokoju z tymi samymi ludźmi, na tym samym terenie i w tym samym czasie" 42 .

Pewne podsumowanie dyskusji na tym etapie stanowiły wnioski z 3325 . posiedzenia Rady Bezpieczeństwa, zrekapitulowane w maju 1993 r. Rada opowiadała się za prowadzeniem przyszłych działań pokojowych przy zachowaniu następujących zasad:

- czytelnego celu politycznego misji z wyraźnie określonym mandatem (przy czym wyłącznie Rada uprawniona była do periodycznej oceny jego wykonywania i ewentualnej modyfikacji);

${ }^{39}$ E.J. Osmańczyk, A. Mango, Encyclopedia of the United Nations and International Agreements, New York 2003, s. 41.

${ }^{40}$ A. Roberts, The Crisis in UN Peacekeeping, „Survival” 1993, vol. 36, no. 2, s. 100 i n.

${ }^{41}$ D. Jablonsky, J.S. McCallum, Peace Implementation and the Concept of Induced Consent in Peace Operations, „Parameters” [Spring] 1999, s. 56.

${ }^{42}$ S. Tharoor, Should UN Peacekeeping Go 'Back to Basis?, „Survival” 1995-1996, vol. 37 , no. 3 , s. 60 . 
- zgody na implementację misji ze strony rządu oraz (o ile to możliwe) stron zaangażowanych w konflikt;

- wspierania politycznego procesu lub pokojowego osiagnięcia porozumienia;

- bezstronności przy implementacji decyzji Rady Bezpieczeństwa;

- gotowości Rady Bezpieczeństwa do sięgnięcia po skuteczne środki przeciwko stronie nie stosującej się do zaleceń Rady;

- prawa Rady Bezpieczeństwa do autoryzacji wszelkich środków niezbędnych dla sił ONZ w celu realizacji mandatu oraz zapewnienia skutecznej samoobrony ${ }^{43}$.

Jakkolwiek w dalszych akapitach Rada zalecała kontynuowanie prac nad zwiększeniem efektywności operacji pokojowych w wymiarach militarnym i pozamilitarnym ${ }^{44}$, to wydźwięk całości dokumentu należy ocenić jako regres w stosunku do idei przewodniej Agendy dla Pokoju. Przede wszystkim zakwestionowano pogląd o możliwościach ekspedycji sił ONZ z pominięciem zgody stron konfliktu. Wśród zasad znalazło swoje potwierdzenie zachowanie monopolu na zarządzanie misjami pokojowymi bezpośrednio przez Radę Bezpieczeństwa, co wobec słusznie podnoszonych wątpliwości odnośnie do możliwości osiagnnięcia porozumienia na płaszczyźnie politycznej w tym gremium, poddawało w wątpliwość elastyczność i skuteczność prowadzenia misji w polu. W dokumencie natomiast kładziono bardzo silny nacisk na zwiększenie komponentu niewojskowego (dyplomacja prewencyjna i „peace-making”), jak również na „współdziałanie z organizacjami regionalnymi”"45. Oceniając stanowisko Rady Bezpieczeństwa, należy stwierdzić, iż zawierało ono bardzo poważne elementy zachowawcze w stosunku do propozycji sprzed roku ${ }^{46}$.

\section{Mandat UNPROFOR - możliwości i ograniczenia}

W tej atmosferze pełnej chwiejności oraz balansowania pomiędzy radykalizmem zmian a zachowawczościa, Organizacja Narodów Zjednoczonych stanęła w obliczu trzech poważnych konfliktów zbrojnych - wojen domowych w Somalii, Bośni i Hercegowinie oraz wojny w Rwandzie - i ludobójstwa o przerażającej skali, jako jej elementu.

Niepodległość Republiki Bośni i Hercegowiny została ogłoszona przez prezydenta Aliję Izetbegovicia 3 marca 1992 r. Do pierwszych starć doszło jeszcze

${ }^{43}$ UN S/25859. Note by the President of the Security Council, 28 V 1993, s. 1.

${ }^{44}$ Tamże, s. 2-3.

45 Tamíe, s. 3-4.

${ }^{46}$ K. Graham, T. Felício, Regional Security and Global Governance. A Study of Interaction Between Regional Agencies and the UN Security Council with a Proposal for a Regional-global Security Mechanism, Brussels 2006, s. 120-121. 
w trakcie trwania referendum, jakie poprzedziło proklamowanie niepodległości. Zanim rozpoczęło się głosowanie, na drogach zostały zbudowane barykady. W ten sposób dokonano pierwszego, opartego na kryterium etnicznym podziału państwa. Walki trwały zarówno między Serbami i Chorwatami, jak i między Chorwatami a Muzułmanami oraz Serbami i Muzułmanami. Początkowo ewentualne sojusze tworzone były doraźnie i w obrębie niewielkich obszarów ${ }^{47}$. Mimo prób mediacji, zasięg konfliktu rozszerzał się i od kwietnia właściwie cała Bośnia i Hercegowina znalazła się w ogniu wojny. Wydarzenia z początku kwietnia - uznanie niepodległości Bośni i Hercegowiny przez USA i Wspólnoty Europejskie, a także inne podmioty międzynarodowe, doprowadziły do zaostrzenia się sytuacji. Głównym punktem starć stało się Sarajewo. Odpowiedzią na to była decyzja podjęta przez Radę Bezpieczeństwa o wysłaniu do bośniackiej stolicy „błękitnych hełmów”, których zadaniem miało być ochranianie lotniska i zapewnienie ciagłości $\mathrm{w}$ dostarczaniu pomocy humanitarnej dla miasta. W tym celu rozszerzono mandat Sił Ochronnych ONZ - UNPROFOR - działających do tej pory tylko na terytorium Chorwacji. Ważne jest, iż siły te miały prawo używania broni wyłącznie w samoobronie ${ }^{48}$.

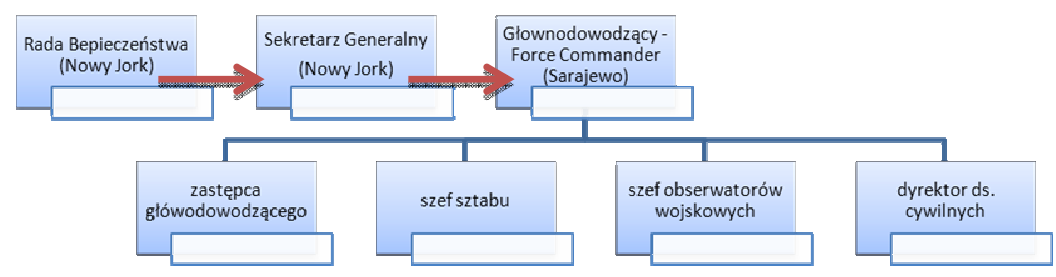

Schemat 3. Łańcuch dowodzenia UNPROFOR na podstawie Raportu Sekretarza Generalnego dla Rady Bezpieczeństwa z 2 kwietnia 1992 r.

Źródło: UN S/23777, Report of the Secretary-General Pursuant to Security Council Resolution 742 (1992), 2 April $1992^{49}$ (oprac. własne).

${ }^{47}$ Szerzej: E. O’Ballance, Civil War in Bosnia 1992-94, Houndmills 1995, s. 9-10.

${ }_{48}$ UNPROFOR powołano na mocy rezolucji nr 743 Rady Bezpieczeństwa ONZ z 21 lutego 1992 r., poczatkowo obszar ich działań obejmował tylko terytorium Chorwacji. Zadaniem UNPROFOR było zapobieganie rozszerzaniu się konfliktu. Zob.: UN Resolution 743 (1992) 21 of February 1992. Na głównodowodzącego tych oddziałów ONZ powołano indyjskiego gen. Satisha Nambiara.

${ }^{49}$ UN S/23777, Report of the Secretary-General Pursuant to Security Council Resolution 742 (1992), 2 April 1992, § 2: „The Force Commander, Lt. General Satish Nambiar, the Deputy Force Commander, Maj. General Philippe Morillon, the Director of Civil Affairs, Mr. Cedric Thornberry, the Chief of Staff, Brig.-Gen. Lewis MacKenzie, and the Chief Administrative Officer, Mr. Keith Walton". 
Decyzję podjęto 8 czerwca na mocy rezolucji nr $758^{50}$. Zakładała ona, że wysłanie wojsk ma być ostatecznym rozwiązaniem, jeśli porozumienia dotyczącego odblokowania stolicy dla dostaw pomocy humanitarnej nie uda się osiagnaćc w inny sposób. Stronie serbskiej przedstawiono ultimatum, w którym żądano udostępnienia sarajewskiego lotniska pod groźbą użycia siły przez ONZ. W dniu upływu ultimatum, 29 czerwca 1992 r. Rada Bezpieczeństwa ONZ postanowiła wysłać wojsko do Sarajewa, a pierwsi żołnierze zaczęli przybywać do miasta 1 lipca $^{51}$. Kolejna rezolucja, z 13 lipca, określała zadania, jakie stawiano przed siłami UNPROFOR. W nawiązaniu do porozumienia z 5 czerwca siły Narodów Zjednoczonych miały nadzorować dyslokację ciężkiej artylerii oraz czołgów do miejsc wyznaczonych oraz monitorować ich użycie. Ponadto „błękitne hełmy” miały strzec bezpieczeństwa korytarzy łączacych lotnisko $z$ miastem ${ }^{52}$. Państwa NATO wraz z Unią Zachodnioeuropejską zaangażowały się w działania na rzecz kontroli przestrzegania nałożonego na obszar konfliktu embarga. W tym celu 10 lipca 1992 r. wysłano na Adriatyk sześć okrętów, których misją było zapobieganie przemytowi towarów uznanych za niedozwolone na mocy decyzji Rady Bezpieczeństwa $^{53}$. W sierpniowym raporcie Specjalnego Sprawozdawcy Komisji Praw Człowieka ONZ, Tadeusza Mazowieckiego, znalazł się postulat zwiększenia zadań sił pokojowych. Mazowiecki postulował m.in. ograniczenie możliwości używania ciężkiej broni przez walczące strony (głównie serbska) i oddanie jej pod kontrolę sił UNPROFOR, których mandat miał objaćc całe terytorium Bośni i Hercegowiny ${ }^{54}$.

Pod względem „rules of engagement” zaangażowanie w Bośni stawiało również nowe i poważne wyzwania. Trzeba mocno podkreślić, że zakres użycia siły znacznie ewoluował podczas trwania misji. Zasady zaangażowania UNPROFOR, podobnie jak rozwiązania przyjmowane dla wcześniejszych misji, należy postrzegać $\mathrm{w}$ dwóch płaszczyznach. Z jednej strony, ograniczenia formułowane $\mathrm{w}$ „rules of engagement” miały wychodzić naprzeciw politycznym oczekiwaniom, iż działania „błękitnych hełmów” nie będą zbyt ryzykowne (straty oddziałów państw demokratycznych mogłyby okazać się wyjątkowo kosztowne politycznie), działania wojsk nie będą zmierzać w stronę brutalności wobec ludności cywilnej (jak pokazały doświadczenia amerykańskie w Wietnamie nieakceptowanej społecznie) ${ }^{55}$ oraz nie będa powodowały dodatkowych znisz-

\footnotetext{
50 UN S/RES/758 (1992), Resolution 758 - 19 of June 1992.

51 UN S/RES/761 (1992), Resolution 761 - 29 of June 1992.

52 UN S/RES/764 (1992), Resolution 764 - 13 of July 1992.

${ }^{53}$ R. Zięba, NATO wobec konfliktów etnicznych na terenie Jugosławii, „Stosunki Międzynarodowe" 2000, nr 1-2, s. 36.

54 Zob. raport z 28 sierpnia 1992 r., [w:] Raporty Tadeusza Mazowieckiego z byłej Jugosławii, [red. R. S. Hliwa i R. Wieruszewski], Poznań-Warszawa 1993, s. 33-52.

55 Szerzej na temat tego problemu zob. M. Waltzer, Triumf wojny sprawiedliwej (i niebezpieczeństwa sukcesu) (2002), [w:] Spór o wojnę, Warszawa 2006, s. 22-25; tenże, Operacje pokojowe (1994), [w:] Spór o wojnę, Warszawa 2006, s. 95-97.
} 
Wpływ doświadczeń z Bośni i Hercegowiny w latach 1992-1995...

czeń $^{56}$. Druga funkcja „rules of engagement” było stworzenie pewnej bazy zasad, które mogliby wykorzystywać w polu dowódcy „błękitnych hełmów” i podlegający im żołnierze, tak, by wykonując swoją misję, nie „wpływali na polityczne rozwiązania" (zgodnie z zasadą bezstronności, obowiąująca w misjach ONZ) ${ }^{57}$. Ten stosunkowo czytelny obraz daleki jednak był od kompletności. Początkowo „zasady zaangażowania” wymagały od dowódców interpretacji dokumentów organów ONZ (głównie Rady Bezpieczeństwa), co w warunkach dowodzenia w polu było niemożliwe do realizacji i zwykle pociagało za sobą zaniechania oraz improwizację $e^{58}$.

Jak pisano powyżej, podstawą działania UNPROFOR była rezolucja Rady Bezpieczeństwa nr 743 z lutego 1992 r. Ona też stanowiła w pierwszej fazie podstawę dla interpretacji działań „błękitnych hełmów”. Zakres zadań dla sił pokojowych nie wykraczał poza cztery sytuacje uprawniające do użycia siły. Ważne jest jednak podkreślenie, że „zasady zaangażowania” nie zostały określone expressis verbis. Wypełnieniem tej luki miał być dokument z 24 marca - Force Commander's Policy Directive 13, Rules of engagement - którego autorem był gen. Jean Cot, od lipca 1993 r. do marca roku następnego głównodowodzący UNPROFOR $^{59}$. W dokumencie, jako podstawę prawną wskazywano raport Sekretarza Generalnego z 11 grudnia 1991 r. do rezolucji Rady Bezpieczeństwa $\mathrm{nr} 721 \mathrm{z}$ listopada ${ }^{60}$. W aneksie do raportu stwierdzono: „Uzbrojony personel objęty będzie trwałymi instrukcjami użycia siły w minimalnym zakresie, wynikającym z potrzeb i samoobrony” 61 . W „rules of engagement” podkreślano, że UNPROFOR wyposażone będą w broń przeznaczoną wyłącznie do celów defen-

56 B.D. Berkowitz, Rules of Engagement for UN Peacekeeping Forces in Bosnia, "Orbis" 1994, vol. 38, no. 3, s. 637 .

${ }^{57}$ A. Sitkowski, UN Peacekeeping. Myth and Reality, Westport 2006, s. 16.

58 B.D. Berkowitz, $d z$. cyt., s. 638 i n. Autor zauważa, że ten aspekt przede wszystkim stanowił o niecheci Stanów Zjednoczonych do wysyłania w takie misje własnych oddziałów. Berkowitz podkreślał różnice pomiędzy ,rules of engagement" przyjmowanych przez ONZ i przez USA, wskazując na znacznie większa złożoność i komplikację tych pierwszych i, wynikajaca z nich, nieprzystawalność do warunków pola operacji. Zob. też: W.J. Durch, J. A. Schear, Faultlines: UN Operations in the Former Yugoslavia, [w:] UN Peacekeeping, American Politics, and the Uncivil Wars of the 1990s, ed. W.J. Durch, New York 1996, s. 227.

${ }^{59}$ Force Commander's Policy Directive 13, Rules of engagement, Part I: Ground forces; Issued: 24 March 1992, revised 19 July 1993 - cyt. za: B.D. Berkowitz, dz. cyt., s. 637 i n.

60 UN S/RES/721 (1991), Resolution 721 - 27 of November 1991; oraz załącznik - UN S/23239: Letter dated on 24 November 1991 from the Secretary-General Addressed to the President of the Security Council; UN S/23280: Report of the Secretary-General of 11 December 1991, [w:] The 'Yugoslav' Crisis in International Law. Part I: General Issues, ed. D.L. Bethlehem, M. Weller, Cambridge 1997, s. 478-479.

${ }^{61}$ UN S/23280: Report of the Secretary-General of 11 December 1991, Annex III, § 4: „Those personnel who were armed would have standing instructions to use force to the minimum extent necessary and normally only in self-defence". 
sywnych, jednocześnie surowo zabroniono stosowania środków odwetowych ${ }^{62}$. W rozszerzeniu zasad z 1993 r. znalazło się stwierdzenie o właczeniu do zakresu pojęcia samoobrony przeciwdziałania siłowym próbom uniemożliwiania elementom misji wykonywania ich obowiązków ${ }^{63}$. Takie rozwiązania możliwe jednak były dopiero po decyzji Rady Bezpieczeństwa, odwołujacej się do mechanizmów rozdz. VII Karty Narodów Zjednoczonych ${ }^{64}$. W dalszych paragrafach określono sytuacje, w których dopuszczalne było użycie broni, grupujac je w trzech kategoriach:

a) obrona własna, innego personelu ONZ lub osób i obszarów znajdujących się w wyznaczonych do ochrony strefach przed bezpośrednim atakiem. Działania zawsze powinny być realizowane zgodnie z rozkazami starszego oficera/żołnierza, znajdującego się na miejscu;

b) przeciwdziałanie siłowym próbom uniemożliwiania wykonywania obowiązków wynikających z mandatu misji;

c) przeciwdziałanie próbom wtargnięcia oddziałów wojskowych lub paramilitarnych do Obszarów Chronionych przez ONZ (UNPAs) i „stref bezpieczeństwa”65.

Szczegółowe przepisy użycia siły zostały sformułowane w złożonej formie, jako przepisy zachowania w konkretnych sytuacjach. Problemem pozostawał fakt, iż zadania stawiane przed UNPROFOR - w szczególności w fazach 3-5 powodowały, że siły Narodów Zjednawczych operowały we wrogim środowisku z zadaniami zabezpieczania „safe area”, ochrony cywilów i monitoringu zwaśnionych stron, bez uwzględnienia w „rules of engagement” środków, które umożliwiałyby wykonywanie zadań skutecznie i przy akceptowalnym poziomie ryzyka ${ }^{6}$. Rozwój wydarzeń potwierdzał te obserwacje.

Jesienne ofensywy wojsk serbskich, które doprowadziły do objęcia kontrola blisko 70\% obszaru kraju ${ }^{67}$, a nade wszystko atak na włoski samolot z pomoca humanitarną (wrzesień 1992 r.) spowodowały, że Rada Bezpieczeństwa zdecydowała się podjać bardziej stanowcze kroki68. 14 września w oparciu o rezolucję

62 Force Commander's Policy Directive 13...: „The use of weapons is authorized normally only in self-defence. Retaliation is forbidden".

${ }_{63}$ Tamże: „Self-defence includes resistance to attempts by forceful means to prevent the Force from discharging its duties under the mandate for the UNPROFOR".

${ }^{64}$ Zob. niżej.

${ }_{65}$ Tamize, § 5: „(a) to defend themselves, other UN personnel, or persons and areas under their protection against direct attack, acting always under the order of the senior officer/soldier at the scene; (b) to resist attempts by forceful means to prevent the Force from discharging its duties; or, (c) to resist deliberate military or paramilitary incursions into the United Nations Protected Areas (UNPAs) or Safe Areas".

${ }^{66}$ Szerzej na temat zadań UNPROFOR w poszczególnych fazach realizacji misji zob.: T. Findlay, $d z$. cyt., s. 222-228.

${ }^{67}$ E. O’Ballance, $d z$. cyt., s. 89-92; zob. też S. Wojciechowski, Integracja i dezintegracja Jugostawii na przetomie XX $i$ XXI wieku, Poznań 2002, s. 86.

${ }_{68}$ S. Economides, P. Taylor, Former Yugoslavia, [w:] The New Interventionism 1991-1994. United Nations Experience in Cambodia, former Yugoslavia and Somalia, ed. J. Mayall, Cambridge 1996, s. 77. 
Wpływ doświadczeń z Bośni i Hercegowiny w latach 1992-1995...

nr 776 postanowiono zwiększyć kontyngent UNPROFOR. Do jego zadań, oprócz ochraniania lotniska i transportów pomocy humanitarnej, należeć miało także wspieranie działalności pracowników biura Wysokiego Komisarza Narodów Zjednoczonych do spraw Uchodźców (UNHCR), monitorujących sytuację na terenach objętych walkami ${ }^{69}$.

Znaczna militarna przewaga Serbów, a także stale napływające informacje o „czystkach etnicznych” i masowym łamaniu praw człowieka na terenach objętych walkami, po raz kolejny zmobilizowały społeczność międzynarodową do działania. W październiku Rada Bezpieczeństwa przyjęła rezolucję nr 781, w myśl której w obszarze powietrznym nad terytorium Bośni i Hercegowiny utworzono strefe zakazu lotów. Dopuszczalne były tylko loty jednostek UNPROFOR, a także innych samolotów wspierających działalność ONZ w Bośni, oraz dostarczające pomoc humanitarną. Żołnierze z „błękitnych hełmów” nadzorować mieli również rozmieszczenie broni ciężkiej wokół kilku bośniackich miast ${ }^{70}$. W akcję tę zaangażowane było także NATO, które udostępniło samoloty Powietrznego Systemu Wykrywania i Powiadamiania (AWACS) do monitorowania przestrzegania zakazu lotów ${ }^{71}$. Warto pamiętać, że pół roku później - 31 marca 1993 r. - Rada Bezpieczeństwa w rezolucji nr 816 wyraziła zgodę na użycie środków militarnych przez NATO, aby zapewnić przestrzeganie zakazu lotów nad terytorium Bośni ${ }^{72}$. Operacji tej nadano kryptonim „Zakaz Lotu” (Deny Flight ${ }^{73}$. Bez wątpienia była ona wymierzona w Serbów, którzy byli jedyną stroną konfliktu posiadającą lotnictwo. W kwietniu wprowadzono dalsze sankcje wobec Jugosławii ${ }^{74}$.

Zaostrzenie się sytuacji międzynarodowej spowodowało kolejne działania sił serbskich. Na poczatku kwietnia 1993 r. ruszyła ofensywa wojsk Serbów bośniackich, mająca na celu zdobycie Srebrenicy, co właściwie udało się osiagnaćc w połowie miesiąca. W czasie trwających już rozmów o poddaniu miasta, Rada Bezpieczeństwa postanowiła nie dopuścić do jego zajęcia przez siły serbskie. W tym celu, pod naciskiem amerykańskim zdecydowano, że Srebrenica zostanie objęta ochrona wojsk ONZ i zdemilitaryzowana ${ }^{75}$. Natomiast 6 maja na mocy rezolucji nr 824 utworzono także wokół innych miast „strefy bezpieczeństwa”, których nie wolno było atakować ${ }^{76}$. Miastami tymi, oprócz Srebrenicy, były: Bihać, Tuzla, Goražde, Žepa oraz stolica - Sarajewo ${ }^{77}$.

69 UN S/RES/776 (1992), Resolution 776 - 14 of September 1992.

70 UN S/RES/781(1992), Resolution 781 - 9 of October 1992.

71 R. Zięba, $d z$,cyt, s 37.

72 UN S/RES/816 (1993); Resolution 816 - 31 of March 1993.

73 E.C. Sloan, Bosnia and the New Collective Security, Westport 1998, s. 22; The 'Yugoslav' Crisis in..., s. 685.

${ }^{74}$ UN S/RES/820, Resolution 820 - 17 of April 1993.

75 UN S/RES/819, Resolution 819 - 16 of April 1993.

${ }^{76}$ Szerzej: C. Rogel, The Breakup of Yugoslavia and its Aftermath, Westport 2004, s. $163-165$.

77 UN S/RES/824, Resolution 824 - 6 of May 1993. 
Właśnie zadanie ochrony „safe areas” stało się głównym celem działań wojsk UNPROFOR. Oddziały „błękitnych hełmów” właściwie od początku swojej obecności w Bośni i Hercegowinie stawały się przedmiotem ataków. Już w listopadzie 1992 r. w okolicach Tuzli w ogniu znaleźli się Brytyjczycy ${ }^{78}$. Również w okolicach Tuzli pod ciężkim ostrzałem znaleźli się Skandynawowie z Nordic Battalion (Nordbat). Jakkolwiek wszystkie części batalionu znajdowały się w ciężkich sytuacjach, największe straty ponieśli Duńczycy ${ }^{79}$. W okolicach Sarajewa w 1993 r. żołnierze francuscy z pełnym rozmysłem nie odpowiedzieli ogniem na ataki Serbów, utrudniających im dyslokację, chcąc uniknąć eskalacji działań. Ostrzał rzeczywiście ustał po trzech kwadransach ${ }^{80}$. W lutym $1994 \mathrm{r}$. Brytyjczycy raportowali o przypadkach ostrzału konwojów z pomocą humanitarną przez „wolnych strzelców” - najprawdopodobniej Chorwatów. Sytuacja sił pokojowych była tym trudniejsza, że obiekty, żołnierze i konwoje pod błękitną flaga atakowane były przez wszystkie walczące w Bośni i Hercegowinie strony. Jeszcze w 1993 r. kolejny głównodowodzacy UNPROFOR w Bośni, belgijski gen. Francis Briquemont, zalecał swoim podkomendnym ,,...] natychmiastowe odpowiadanie [ogniem] w ciagu kilku sekund od ataku" ${ }^{2}$. W podobnym duchu wypowiedziała się Rada Bezpieczeństwa w rezolucji z 19 lutego 1993 r., powierzając Sekretarzowi Generalnemu kompetencję: „[...] podejmowanie [...] wszelkich adekwatnych kroków na rzecz wzmocnienia bezpieczeństwa UNPROFOR, w szczególności poprzez zapewnienie niezbędnych do samoobrony środków" ${ }^{2}$. Po raz pierwszy też Rada zwróciła uwagę na to, iż UNPROFOR działał w oparciu o rozdz. VII Karty NZ, co było istotne $\mathrm{z}$ uwagi na zakres użycia siły i jego umocowanie prawne. Wydaje się, że od wiosny 1993 r. oddziały ONZ w Bośni i Hercegowinie dysponowały odpowiednim umocowaniem prawnym dla użycia siły w celu realizacji zadań. W szczególności „rules of engagement” zostały sformułowane tak, by dawać możliwości użycia siły w stopniu w pełni adekwatnym do zapewnienia własnego bezpieczeństwa. Zasadne jednak, w świetle następnych wydarzeń, jest podkreślenie, że za konstrukcjami prawnymi nie poszło zwiększenie możliwości operacyjnych ${ }^{83}$, co spowodowane było w znacznej mierze brakiem możliwości technicznych, a nade wszystko brakiem woli politycznej większego zaangażowania militarnego ${ }^{84}$. W sferze „mandatowej” misja

78 T. Findlay, $d z$. cyt., s. 220. Brytyjski płk Alistair Duncan wspominał, że podczas swojej zmiany oddział dowodzony przez niego w walkach znalazł się aż 69 razy.

79 R. Dalsjö, Sweden and Balkan Blue Helmet Operations, [w:] Solidarity and Defence: Sweden's Armed Forces in International Peace-keeping Operations during the 19th and 20th Centuries, ed. L. Ericson, Stockholm 1995, s. 111.

80 T. Findlay, $d z$. cyt., s. 221.

${ }^{81}$ Tamże, s. 221

82 UN S/RES/807, Resolution $807-19$ of February 1993, $\$ 8$.

83 O słabości kontyngentów: R.F. Baumann, G.W. Gawrych, W.E. Kretchic, Armed Peacekeepers in Bosnia, Fort Leavenworth 2004, s. 26-27.

${ }^{84}$ M.W. Doyle, N. Sambanis, $d z . c y t .$, s. 166-167. 
Wpływ doświadczeń z Bośni i Hercegowiny w latach 1992-1995...

w Bośni i Hercegowinie coraz bardziej zmierzała w stronę „peaceenforcement”, podczas gdy możliwości bojowe pozostawały na poziomie ,peacekeeping”. Sytuacja w terenie (i tym samym wyzwania operacyjne) była o tyle skomplikowana, że o ile pewne sukcesy przynosily negocjacje $\mathrm{z}$ walczacymi stronami, to $\mathrm{w}$ wyniku zanarchizowania środowiska wojennego, na całym obszarze konfliktu operowały grupy o charakterze bandyckim, właściwie przez nikogo nie kontrolowane. Ponadto powszechna była nieufność odnośnie do rzeczywistych celów humanitarnej pomocy ONZ. Walczace strony niejednokrotnie utrudniały drogę konwojom ONZ, wychodząc z założenia, że beneficjentami pomocy będą przeciwnicy ${ }^{85}$. Jakkolwiek można się zastanawiać, czy oddziały UNPROFOR dysponowały odpowiednimi możliwościami, by siłą torować drogę konwojom humanitarnym ${ }^{86}$, nie ulega wątpliwości, że ewentualny rozwój sytuacji, spowodowany eskalacją konfliktu, mógł znacznie wykroczyć poza możliwości operacyjne „błękitnych hełmów”. Warto też pamiętać, że wojsko stanowiło osłonę konwojów, w których trzon stanowili jednak pracownicy cywilni UNHCR. Dowódcy osłon konwojów znacznie częściej wybierali środki niezagrażajace starciami. Brytyjczycy, Kanadyjczycy i Francuzi często odwoływali się do „handlu” z lokalnymi oddziałami, utrzymujacymi blokady. Z danych za rok 1993 wynika, że w efekcie takich działań około $23 \%$ ogółu pomocy humanitarnej wpadło w ręce serbskich dowódców polowych. Brytyjczycy i Francuzi ponadto zgadzali się na „kontrole etniczne" personelu konwojów ${ }^{87}$. W sytuacji, w której za priorytet stawiano zachowanie bezstronności oddziałów międzynarodowych, niejednokrotnie dochodziło do biernej akceptacji przewagi strony silniejszej - w większości przypadków Serbów. Zdecydowanie ostrzej reagowali Skandynawowie. Odnotowano przypadki grożenia bronią indywidualną oraz użyciem czołgów przez dowódców szwedzkich ${ }^{88}$. Sytuację dobrze podsumował F. Briquemont, mówiąc: „Istnieje olbrzymia przepaść pomiędzy rezolucjami Rady Bezpieczeństwa, [polityczna] wolą ich realizacji, a możliwościami, pozostającymi w gestii dowódców w terenie" 89 .

Jedno z największych upokorzeń, jakich doznała w latach 90. XX w. ONZ, związane było z wydarzeniami w Srebrenicy latem 1995 r. W przyszłości właśnie ten dramat miał posłużyć jako podstawa do „wyciagania wniosków”. Jeszcze w kwietniu 1993 r. Rada Bezpieczeństwa, wobec narastającego napięcia w rejonie

85 E.C. Sloan, $d z$. cyt., s. 21 i n.

86 Takie przekonanie wyrażają W.J. Durch, J.A. Schear, dz. cyt., s. 267.

87 J.M.O. Sharp, Honest Broker or Perfidious Albion? British Policy in former Yugoslavia, London 1997, s. 18

88 Tamize, s. 19. Autorka przytacza fragment przesłuchania Dunki, która na pytanie, dlaczego oddała 700 strzałów do nacierających Serbów, odpowiedziała: „Nie miałam więcej”.

${ }^{89}$ Cyt. za: T. Findlay, $d z$. cyt., s. 224 - „There is a fantastic gap between the resolutions of the Security Council, the will to execute those resolutions and the means available to commanders in the field". 
Srebrenicy, raportowanego przez gen. Philippe’a Morillon ${ }^{90}$ miesiąc wcześniej, przyjęła rezolucję nr $819^{91}$. Postanowiono, iż miasto stanie się „strefą bezpieczeństwa” (safe area), wolną od ataków i innych wrogich aktów. Paramilitarne grupy bośniackich Serbów miały wycofać się z terenu Srebrenicy, do której przewidywano swobodny dostęp UNPROFOR oraz organizacji humanitarnych ${ }^{92}$. UNPROFOR miały „zwiększyć swoja obecność” na terenach objętych strefa. Wkrótce podobne regulacje zostały określone dla miast: Tuzla, Žepa, Goražde, Bihać i Sarajewo ${ }^{93}$.

Według wiarygodnych źródeł instalacja „stref bezpieczeństwa” ONZ w miastach zaczęła przynosić efekty właściwie od roku 1994, bowiem wcześniej, mimo ustaleń, zwaśnione strony nadal prowadziły ze sobą walki. Napięta sytuacja w Srebrenicy wymusiła skierowanie batalionu holenderskiego, który ulokowany został w pobliskiej wiosce Potočari w styczniu 1995 r. ${ }^{94}$ Wyposażenie, którym dysponowali Holendrzy, okazało się niewystarczające - w wyniku oporu strony serbskiej - batalion nie został zaopatrzony w czołgi i lekkie śmigłowce. W istniejącej sytuacji niewystarczający okazał się również mandat, który przez holenderski parlament został zdefiniowany na poziomie klasycznych i „miękkich” misji utrzymywania pokoju ${ }^{95}$.

Wydarzenia z połowy 1994 r. stanowiły wyraźne sygnały rosnącego napięcia i pogarszającej się sytuacji oddziałów ONZ. Mimo zawarcia czteromiesięcznego rozejmu, który wszedł w życie 1 stycznia 1995 r., daleko było do osiagnięcia trwałego spokoju ${ }^{96}$. Chorwaci przystapili do ofensywy, zmieniając istotnie chwiejna równowagę na frontach. Wywołało to reperkusje w postaci zdecydowanych działań bośniackich Serbów ${ }^{97}$. Już w kwietniu sytuacja w Bośni i Hercegowinie zaostrzyła się i skomplikowała, a siły serbskie doprowadziły do odcięcia „stref bezpieczeństwa”. Na początku lipca bośniaccy Serbowie rozpoczęli ostrzał strefy wokół Srebrenicy, realizując zamysł likwidacji tych enklaw. Do strefy trafiło dodatkowo około 6 tys. uchodźców, których holenderski batalion właściwie

90 Tamże, s. 227.

91 Resolution 819 (1993) Adopted by the Security Council at its 3199th meeting, on 16 April 1993, UN S/RES/819 (1993).

92 Tamże, s. 2-3.

${ }_{93}$ Resolution 824 (1993) Adopted by the Security Council at its 3208th meeting, on 6 May 1993, UN S/RES/824 (1993)

$94 \mathrm{http}: / /$ srebrenica.brightside.nl/srebrenica/, sec. 10 (dostep 25 I 2011).

${ }_{95} \mathrm{Na}$ temat konstrukcji i wyposażenia batalionu holenderskiego zob. Ch. Klep, D. Winslow, Learning Lessons the Hard Way - Somalia and Srebrenica Compared, [w:] Peace Operations between War and Peace, ed. E.A. Schmidl, New York 2000, s. 96-97.

${ }_{96}$ M. Kuczyński, Bałkańska pożoga. Wojny i konflikty na Bałkanach w latach 19811999, Warszawa 1999, s. 95-96.

97 Szerzej: S. Wojciechowski, Wojna w Bośni i Hercegowinie, [w:] Zbrojne konflikty $i$ spory międzynarodowe u progu XXI wieku. Analiza problemowa $i$ studia przypadków, red. W. Malendowski, Wrocław 2003, s. 324 i n. 
Wpływ doświadczeń z Bośni i Hercegowiny w latach 1992-1995...

nie mógł ochronić98. Tym bardziej że 9 lipca, w związku z zamykaniem się serbskiego pierścienia wokół Srebrenicy, do niewoli trafiło 30 Holendrów ${ }^{99}$. Następnego dnia siły holenderskie otrzymały niewielkie wsparcie lotnictwa, które rozpoczęło bombardowanie pozycji serbskich, jednak wobec groźby zabicia pochwyconych „błękitnych hełmów”, akcja została przerwana ${ }^{100}$. 11 kwietnia Srebrenice zajęły oddziały Ratko Mladicia. Ze strony serbskiej wypłynęła oferta przeprowadzenia przez siły ONZ ewakuacji blisko 20-tysięcznej rzeszy uchodźców znajdujących się w Potočari, która została przez Organizację odrzucona ${ }^{101}$. Wobec odmowy Serbowie przeprowadzili akcję selekcji, której efektem miało być wydzielenie wszystkich mężczyzn w wieku 12-77 lat ${ }^{102}$. 13 lipca Muzułmanie otrzymali polecenie opuszczenia obozu, co zostało podyktowane kończeniem się zapasów żywności i wody. W następnych dniach w okolicy Srebrenicy serbskie oddziały wykonywały masowe egzekucje, w których do 16 lipca zginęło około 7,5 tys. osób ${ }^{103}$. Akcje likwidacyjne o mniejszym natężeniu trwały w pobliskich górach jeszcze kilka tygodni ${ }^{104}$.

Właśnie 16 lipca Serbowie zgodzili się na ewakuację sił holenderskich, które musiały w Potočari zostawić cały sprzęt i broń. Ta bezprecedensowa porażka sił pokojowych dość szybko wywołała szerokie reperkusje zarówno w samej Organizacji, jak też w Holandii. Lipcowa aktywność Rady Bezpieczeństwa charakteryzowała się znacznym chaosem i brakiem orientacji w odniesieniu do wydarzeń w Bośni i Hercegowinie. Dobitną tego ilustracją była rezolucja nr 1004 z 12 lipca 1995 r., w której żądano wycofania sił serbskich z rejonu Srebrenicy, uwolnienia personelu ONZ i, co najbardziej kuriozalne, użycia przez Sekretarza Generalnego wszelkich dostępnych środków w celu przywrócenia „strefy bezpieczeństwa" wokół miasta ${ }^{105}$. W opublikowanym siedem lat po tragedii w Srebrenicy raporcie Holenderskiego Instytutu Dokumentacji Wojennej (Nederlands Instituut voor Oorlogsdocumentatie) podkreślono, iż w sytuacji z lipca 1995 r.

98 T. Findlay, $d z$. cyt., s. 250

${ }_{99}$ N. Both, From Indifference to Entrapment. The Netherlands and the Yugoslav Crisis 1990-1995, Amsterdam 2000, s. 192.

100 http://srebrenica.brightside.nl/srebrenica/toc/p3_c01_s015_b01.html, sec. 14 (dostęp 25 I 2011)

101 http://srebrenica.brightside.nl/srebrenica/toc/p3_c01_s015_b01.html, sec. 15 (dostęp 21 I 2011)

102 S.L. Burg, P.S. Shoup, The War in Bosnia-Herzegovina. Ethnic Conflict and International Intervention, New York 1999, s. 180-181.

${ }^{103}$ Dane Międzynarodowego Trybunału Karnego dla byłej Jugosławii - http://www.un. org/icty/cases-e/index-sre.htm (dostęp 22 XII 2010). Zob. też: R. Wieruszewski, Społeczność międzynarodowa wobec masowych naruszeń praw człowieka w byłej Jugosławii, „Sprawy Międzynarodowe” 1998, nr 3, s. 102. 21 I 2011)

$104 \mathrm{http} / / /$ srebrenica.brightside.nl/srebrenica/toc/p3_c01_s018_b01.html, sec. 18 (dostęp

105 Resolution 1004 (1995) Adopted by the Security Council at its 3553rd meeting on 12 July 1995, UN S/RES/1004 (1995), § 6. 
najprawdopodobniej również większe i lepiej wyposażone siły nie byłyby w stanie istotnie wpłynąć na rozwój wydarzeń w Srebrenicy. Jednak, co podkreślano z cała moca, ta sytuacja wygenerowana została w efekcie wcześniejszych zaniechań i braku stanowczości w użyciu środków siłowych ${ }^{106}$.

\section{„Wyciąganie wniosków”}

Jeszcze przed „kompromitacją w Srebrenicy” w ONZ pojawiły się przekonywające sygnały o wycofywaniu się Sekretarza Generalnego z linii przyjętej w Agendzie dla Pokoju. W styczniu 1995 r. opublikowany został Suplement do Agendy dla Pokoju107. W stosunku do głównego nurtu refleksji wokół operacji pokojowych dokument stanowił wyraźny regres. Sekretarz Generalny opowiadał się za powrotem do traktowania elementów siłowych w misjach pokojowych ściśle w odniesieniu do rozdz. VII Karty $N Z^{108}$. W następnych paragrafach stwierdzano, że łączenie tradycyjnych elementów „peacekeeping” - zgody stron konfliktu, prawa do użycia siły wyłącznie w samoobronie oraz bezstronności - z „wymuszaniem pokoju" okazało się niewłaściwe ${ }^{109}$. Prowadziło to do odrzucenia projektów zmierzających $\mathrm{w}$ stronę stworzenia ciagłości operacji z zakresu rozdziałów: VI, „VI i pół” i VII Karty Narodów Zjednoczonych. W zakresie zarządzania operacjami pokojowymi Sekretarz opowiadał się za swoistym „monopolem” Rady Bezpieczeństwa, potwierdzając model istniejący od czasów UNEF. W dokumencie stwierdzano:

(a) Ogólne określanie kierunku politycznego [...] należy do Rady Bezpieczeństwa; (b) za kwestie wykonawcze i sprawy dowodzenia, odpowiedzialny jest Sekretarz Generalny; (c) w zakresie dowodzenia w terenie, wynikającego z decyzji Sekretarza Generalnego, władza należy do szefa misji (specjalnego przedstawiciela Sekretarza Generalnego lub dowódcy sił wojskowych/szefa obserwatorów wojskowych). Różnice pomiędzy tymi trzema poziomami powinny pozostawać wyraźne, w celu uniknięcia nieporozumień co do funkcji i obowiązków. Dowódca misji nie może brać na siebie kształtowania ogólnych celów politycznych, podobnie nieodpowiednie jest pozostawianie w gestii Rady Bezpieczeństwa lub Sekretarza Generalnego znajdujących się w Nowym Jorku, decydowania o sprawach, które wymagają szczegółowego rozpoznania warunków operacyjnych w terenie ${ }^{110}$.

$106 \mathrm{http}: / /$ srebrenica.brightside.nl/srebrenica/ (dostep 22 I 2011).

107 Supplement to an Agenda for Peace: Position Paper of the Secretary-General on the Occasion of the Fiftieth Anniversary of the United Nations, Report of the Secretary-General on the Work of the Organization, UN A/50/60 - S/1995/1, 3 I 1995.

${ }_{108} \mathrm{~A} / 50 / 60-\mathrm{S} / 1995 / 1, \S 33$

109 Tamże, §§ 34-37.

110 Tamże, $\$ 38$ i n. 
Co prawda dostrzegano potrzebę budowy Sił Szybkiego Reagowania ONZ, jednak ich formuła i system dowodzenia pozostawały w sferze mglistych projektów ${ }^{111}$.

$\mathrm{Na}$ tle podejścia do użycia siły doszło do poważnych rozbieżności pomiędzy Sekretarzem Generalnym a Sekretariatem, w szczególności Departamentem Operacji Pokojowych, kierowanym przez Kofiego Annana. O ile część członków Departamentu opowiadała się za utrzymaniem formuły niewłączania „peacekeeping” i „peaceenforcement" do jednego kontinuum ${ }^{112}$, to opowiadano się jednak za zdecydowanym usprawnieniem mechanizmów umożliwiających sięgnięcie do siły, jako sposobu ochrony misji i jej mandatu. Sam szef Departamentu niejednokrotnie wyrażał opinie sytuujące go wśród zwolenników szerokiego i elastycznego pojmowania utrzymywania pokoju:

Dzisiejsze konflikty w Somalii oraz Bośni i Hercegowinie spowodowały fundamentalne przewartościowania w parametrach [operacji pokojowych - J.R.-Z.]. Niewystarczające już sa: implementacja porozumień pokojowych i rozdzielanie antagonistów; społeczność międzynarodowa oczekuje dziś od Organizacji Narodów Zjednoczonych działań polegających na demarkacji granic, kontroli i usuwania ciężkiego uzbrojenia, powstrzymywania anarchii oraz gwarantowania dostaw pomocy humanitarnej do stref konfliktu. Takie zadania w oczywisty sposób wymagaja «zębów» i «mięśni», które wzmocnią mniej wymierne wartości, jakich nie szukaliśmy w przeszłości. Inaczej mówiąc, rosną oczekiwania, że Narody Zjednoczone wymuszą pokój, co było wszak przewidywane w Karcie, u zarania Organizacji113.

Podsekretarz definiował przyszłość operacji pokojowych, jako zjawiska wielowymiarowego, w którym obok tradycyjnego komponentu, pojawić się musiały skuteczne możliwości wymuszania ${ }^{114}$. Dalej, jako innego rodzaju remedium sugerował scedowanie części obowiązków ONZ na organizacje regionalne, posiadajace znaczne możliwości działania - przede wszystkim NATO ${ }^{115}$.

Nowy impuls do działania Organizacji, w zakresie przewartościowań w łańcuchu dowodzenia i konstrukcji mandatu operacji pokojowych, dało objęcie urzędu Sekretarza Generalnego przez dotychczasowego szefa Departamentu Operacji Pokojowych, K. Annana. Już wcześniej pod auspicjami Departamentu podjęto prace nad przygotowaniem ,podręcznika” operacji pokojowych. Pierwsza taka publikacja ujrzała światło dzienne w grudniu 1995 r. ${ }^{116}$ Mimo sporego osiagnięcia, jakim była, autorzy unikali podejmowania dyskusji dotyczącej

111 Tamże, § 42 .

112 S. Tharoor, $d z$. cyt., s. 60-61.

113 K.A. Annan, UN Peacekeeping Operations and Cooperation with NATO, „NATO

Review" 1993, vol. 47, no. 5, s. 5-6.

${ }_{114}$ Tamize, s. 3 .

115 Tamże, s. 7.

116 D.J. Francis, M. Faal, J. Kabia, A. Ramsbotham, Dangers of Co-deployment. UN Co-operative Peacekeeping in Africa, Bradford 2005, s. 44-48. 
ewentualnego rozwinięcia zagadnienia użycia siły w „klasycznych” operacjach pokojowych. Postulowano podejście tradycyjne, w myśl którego utrzymywanie pokoju powinno pozostać wyraźnie oddzielone od elementów siłowych ${ }^{117}$. Podobne stanowisko zajęto w opublikowanym podręczniku szkoleniowym. Warto jednak zauważyć, iż podobnie jak w tezach głoszonych przez K. Annana w 1993 r., zakładano wykorzystanie w fazach siłowych organizacji regionalnych ${ }^{118}$. W tym dokumencie można dopatrywać się swoistego „powiewu” przed nastaniem „ery Kofiego Annana”119, która zaznaczyła się zupełnie innym podejściem do problematyki operacji pokojowych - w szczególności do kwestii użycia siły w interwencji humanitarnej. Nowy Sekretarz Generalny objał urzad 1 stycznia 1997 r. i już wkrótce zarysował nowe podejście do problematyki „zarządzania pokojem”. Główny nacisk położony został na „wymuszanie” (inducement), zarówno w jego negatywnym wymiarze (coercive inducement), jak pozytywnym (positive inducement ${ }^{120}$. Rozwinięcie tej „filozofii” legło u podstaw podejścia do kwestii operacji pokojowych, jakie znalazło swoje odbicie w dwóch kolejnych raportach, przygotowanych na przestrzeni połowy roku (przełom lat 1999/2000).

W połowie listopada 1999 r. wydany został Raport Sekretarza Generalnego odnoszaccy się do rezolucji Zgromadzenia Ogólnego 53/35 z 30 listopada 1998 r. ${ }^{121}$ $\mathrm{W}$ porównaniu z poprzednimi raportami generowanymi przez Lessons Learned Unit (LLU), przytoczony raport wyróżniał się rozmiarami, a tym samym szczegółowością i kompleksowym ujęciem. Inną cecha, właściwą temu dokumentowi, była znaczna doza krytycyzmu wobec działań Organizacji i przyjmowanych regulacji w odniesieniu do sytuacji z lipca 1995 r. w Bośni i Hercegowinie. Bazę dla stworzenia Raportu stanowiły opinie ponad 100 ekspertów i urzędników, zaangażowanych w tworzenie i utrzymywanie „stref bezpieczeństwa” w Bośni i Hercegowinie. W konkluzji Raportu znalazło się stwierdzenie, iż z powodu błędów w ocenie, licznych pomyłek i braku zdolności rozpoznania problemu, Organizacja Narodów Zjednoczonych nie była w stanie „uratować ludzi ze Srebrenicy przez serbska kampanią masowych mordów”122. W dokumencie

117 General Guidelines of Peace-keeping Operations, UN 95-38147, s. 20-21.

118 Por. Report on Sharing Responsibilities in Peace-Keeping: The United Nations and Regional Organizations, JIU/REP/95/4, Geneva 1995, s. 14.

119 Określenie zaczerpnięte z pracy T. Findlaya, $d z$. cyt., s. 326. Zob. też: N. Fenton, Understanding the UN Security Council. Coercion Or Consent?, London 2004, s. 29-30.

120 Do pierwszej grupy działań wchodziły m.in. akcje wymuszające (peaceenforcement) i sankcje. Grupa druga zawierała akcje cywilne i „bodźce” pokojowe. Szerzej: K. Annan, Challenges of the New Peacekeeping, [w:] Peacemaking and Peacekeeping for the New Century, ed. O.A. Otunnu, M.W. Doyle, Lanham 1998, s. 174-177. Sekretarz podkreślał różnice pomiędzy kategoriami pozytywnego wymuszania i akcjami humanitarnymi, która leżała w sferze planowanego efektu - tamize, s. 177.

121 Resolution Adopted by the General Assembly (53/35). The Situation in Bosnia and Herzegovina, A/RES/53/35, 13 January 1999.

122 Report of the Secretary-General pursuant to General Assembly Resolution 53/35: The Fall of Srebrenica, UN A/54/549, 15 XI 1999, §503. 
Wpływ doświadczeń z Bośni i Hercegowiny w latach 1992-1995...

niejednokrotnie podkreślano żenująca słabość militarną holenderskiego kontyngentu, wynikająca $\mathrm{z}$ jednej strony $\mathrm{z}$ braków sprzętowych, $\mathrm{z}$ drugiej strony z ograniczeń płynących ze sformułowania mandatu ${ }^{123}$. W Raporcie znalazł się szczegółowy opis wydarzeń wokół „strefy bezpieczeństwa” w Srebrenicy, ilustrujaccy rozwój wypadków w perspektywie kolejnych godzin ${ }^{124}$. Narracja nie pozostawiała watpliwości - od początku lipca narastała ilość sygnałów świadczących o zbliżającej się katastrofie, natomiast odpowiednie agendy decyzyjne nie były w stanie przedsięwziąć żadnych skutecznych kroków. Krytycznie odniesiono się do debaty poprzedzającej przyjęcie rezolucję Rady Bezpieczeństwa nr 1004, podczas której, mimo przyjęcia zdecydowanego tonu, rządy wielu krajów (głównie Francji i Włoch) opatrzyły decyzje tak wieloma zastrzeżeniami, iż rezolucja stawała się pusto brzmiącym tekstem ${ }^{125}$. W omówieniu politycznej sytuacji w Bośni i Hercegowinie znalazło się gorzkie stwierdzenie, iż nie doceniono kompleksowości i złożoności problematyki całości operacji w Bośni, co kładło się cieniem na politycznej aktywności ONZ ${ }^{126}$. Środki zapobiegawcze, jak też sankcje nałożone na walczace strony, okazały się - zdaniem autorów Raportu - daleko niewystarczajace, by zapobiec masakrom. Gdy w czerwcu 1995 r. zaistniał właściwy klimat, by UNPROFOR zostały wyposażone w adekwatne środki siłowe, inicjatywy te spotkały się z negatywnym stanowiskiem Sekretariatu i Rady Bezpieczeństwa ${ }^{127}$. Sekretarz nie pozostawiał wątpliwości, iż to właśnie agendy ONZ, poprzez zaniechania i opóźnianie procesu decyzyjnego i implementacyjnego, ponosiły znaczną część odpowiedzialności za rozwój sytuacji do tak bolesnego efektu $^{128}$. W ostatnich słowach dokumentu K. Annan wyrażał nadzieję, że gorzkie doświadczenia z tragedii w Srebrenicy uzmysłowia członkom Narodów Zjednoczonych konieczność „usprawnienia zdolności [...] odpowiadania na różne rodzaje konfliktu”. Raz jeszcze podkreślał „nieadekwatność symbolicznego zapobiegania w obliczu systematycznej kampanii przemocy"129. W odniesieniu do użycia siły, K. Annan wyraźnie dawał do zrozumienia, iż brak zdecydowanych działań we wczesnej fazie konfliktu znacznie zwiększa prawdopodobieństwo jego eskalacji i, w konsekwencji, powiększenia kosztów przywrócenia pokoju. Znacznie wyższe przy takich zaniechaniach było również prawdopodobieństwo wymknięcia się kryzysu spod kontroli i przejścia w fazę humanitarnej katastrofy.

Warto podkreślić, iż żaden z wcześniejszych dokumentów nie posiadał aż tak skumulowanego ładunku krytycyzmu w stosunku do działań i mechanizmów Organizacji Narodów Zjednoczonych. O ile wcześniejsze raporty koncentrowały

\footnotetext{
123 UN A/54/549, $\S 472-475$.

124 Tamże, $\$ 259$ i n.

125 Tami்e, $\$ \S 331-340$.

126 Tamże, $\$ \$ 485-488$.

127 Tamíe, § 490 .

128 Tamże, § 501

129 Tami̇e, § 505
} 
się raczej na refleksjach dotyczących samego wykonywania misji, o tyle Report of the Secretary-General pursuant to General Assembly Resolution 53/35: The Fall of Srebrenica dotykał głębokiej istoty problemu - zwracając uwagę na problemy strukturalne i decyzyjne w samym Sekretariacie oraz Radzie Bezpieczeństwa. Sporo uwagi poświęcono również kwestii współdziałania z organizacjami regionalnymi, przede wszystkim NATO (chodziło o kontekst zgrania operacji powietrznych). I tu dostrzegano istotne problemy strukturalne oraz wynikajace $\mathrm{z}$ nich braki w procesie komunikowania i koordynacji ${ }^{130}$. Na szczególną uwagę zasługuja słowa: „Aby zapewnić, że wyciąnęliśmy wnioski z tragicznych wydarzeń, opisanych $\mathrm{w}$ niniejszym sprawozdaniu, pragnę zachęcić państwa członkowskie do zaangażowania się w proces refleksji i analizy, koncentrujący się na śledzeniu tendencji w kluczowych wyzwaniach [przed jakimi stajemy - J.R.-Z]. Celem tego procesu będzie określenie wad i poprawienie zdolności ONZ do reagowania na różne formy konfliktu. Mam na myśli takie kwestie, jak rozziew między mandatem i środkami na jego realizację, niedoskonałości odstraszania w obliczu systematycznych kampanii przemocy, wszechobecna ambiwalencja w łonie Narodów Zjednoczonych, dotycząca roli siły w dążeniu do pokoju, instytucjonalne następstwa utrzymywania zasady bezstronności (nawet w obliczu próby ludobójstwa) i zakres doktrynalnych i instytucjonalnych kwestii, które składaja się na sedno zdolności ONZ do utrzymania pokoju i ochrony ludności cywilnej przed następstwami konfliktów zbrojnych". Nie ulega wątpliwości, że w sposób trafny diagnozowały one wielostopniowość problemu. Nawet w przypadku osiagnięcia adekwatnego zakresu mandatu dla operacji pokojowej (poziom polityczny), jego implementacja napotykała barierę braku zdolności operacyjnych na obszarze konfliktu (poziom operacyjny, warunkowany politycznie). Posiadając zaś ograniczone środki, dowódcy misji na różnych poziomach działali w sposób zachowawczy, wychodząc z założenia, że priorytetem $\mathrm{w}$ misji jest utrzymanie bezpieczeństwa własnych żołnierzy (poziom taktyczny). Właśnie na tym tle w ostatnich kilku latach rozgorzał spektakularny spór pomiędzy kanadyjskimi generałami Lewisem MacKenzie a Roméo Dallairem ${ }^{131}$. Podobnie jak różnica stanowisk obu oficerów, tak trudności w formułowaniu i wykonywaniu misji ONZ z użyciem siły, wydają się nierozwiązywalne.

${ }^{130}$ Tami்e, $\S 480$.

${ }^{131}$ L. MacKenzie, Soldiers Made Me Look Good. A Life in the Shadow of War, Vancouver-Toronto-Berkeley 2008, s. 214 i n.; zob. też: Dallaire's Deadly Error, 20 VIII 2008, http://www.macleans.ca/canada/national/article.jsp?content=20080820_93682_93682 (dostęp 29 I 2011). 